\title{
A retrospective study of the pre-eruptive unrest on El Hierro (Canary Islands): implications of seismicity and deformation in the short-term volcanic hazard assessment
}

\author{
Stefania Bartolini $^{1}$, Carmen López ${ }^{2}$, Laura Becerril ${ }^{1}$, Rosa Sobradelo ${ }^{3}$, and Joan Martí ${ }^{1}$ \\ ${ }^{1}$ Group of Volcanology, (SIMGEO-UB) CSIC, Institute of Earth Sciences Jaume Almera, \\ c/Lluis Sole Sabaris s/n, 08028 Barcelona, Spain \\ ${ }^{2}$ Observatorio Geofísico Central, Instituto Geográfico Nacional (IGN), c/Alfonso XII, 3, 28014 Madrid, Spain \\ ${ }^{3}$ Willis Research Network and Analytics Technology, Willis Towers Watson, London, UK
}

Correspondence: Stefania Bartolini (sbartolini.1984@gmail.com)

Received: 30 June 2017 - Discussion started: 10 July 2017

Revised: 21 April 2018 - Accepted: 24 May 2018 - Published: 22 June 2018

\begin{abstract}
The correct identification and interpretation of unrest indicators is useful for forecasting volcanic eruptions, delivering early warnings, and understanding the changes occurring in a volcanic system prior to an eruption. Such indicators play an important role in upgrading previous long-term volcanic hazard assessments and help explain the complexities of the preceding period of eruptive activity. In this work, we present a retrospective analysis of the 2011 unrest episode on the island of El Hierro, Canary Islands, that preceded a submarine eruption. We use seismic and surface deformation monitoring data to compute the susceptibility analysis (QVAST tool) and to study the evolution over time of the unrest (ST-HASSET tool). Additionally, we show the advantages to be gained by using continuous monitoring data and hazard assessment e-tools to upgrade spatiotemporal analyses and thus visualize more simply the development of the volcanic activity.
\end{abstract}

\section{Introduction}

The most challenging aspect of forecasting volcanic eruptions is the correct identification and interpretation of precursors during the episodes of unrest that normally precede eruptive activity. During this phase, the short-term volcanic hazard assessment can be computed by combining a longterm hazard analysis with real-time monitoring data, updating continuously the status of the volcanic hazard (Blong,
2000; Sobradelo and Martí, 2015; Tonini et al., 2016). Shortterm evaluations can help forecast the likely outcomes - i.e., where and when the eruption will take place - by drawing on the information derived from indicators and an understanding of the volcanic system. The parameters associated with the volcanic process are the geophysical and geochemical signals that provide information on magma movement within the volcanic system and on how the magma is preparing to reach the surface (Chouet, 1996; McNutt, 1996).

In particular, the signals recorded during unrest episodes - for example, an increase in activity compared to the previous background level (Phillipson et al., 2013) - can be used to deduce changes in magma accumulation and movement, the state of stress of the host rock, and the physical and chemical properties of the magma itself (Harrington and Brodsky, 2007; Jellinek and Bercovici, 2011; Lavallée et al., 2008; McNutt, 2005; Neuberg et al., 2000; Papale, 1999; Tárraga et al., 2014). A comprehensive, well-organized monitoring network on and around the volcano is fundamental if scientists are to analyze how the eruption process is evolving. Changes may be detected on the surface that reflect variations in the geophysical (e.g., seismicity, surface deformation, and changes in potential fields) and/or geochemical (e.g., gas flow rate and gas composition) parameters sensed by the network that is monitoring the activity of the volcano (Scarpa and Tilling, 1996; Sparks, 2003; Vallianatos et al., 2013; Telesca et al., 2015).

It is essential that all the monitoring information obtained during an unrest phase be processed and interpreted in real 
time. This is a crucial consideration since this information is vital in eruption forecasting and provides support for decision-makers. In many instances during an unrest phase, the institution in charge of the monitoring network is expected to publish daily or even hourly bulletins with updates derived from monitoring signals. These bulletins are then used by experts (e.g., a scientific committee or crisis team) to keep public officials abreast of the state of the volcanic system. These reports do not generally contain probabilistic model results and tend to consist merely of processed monitoring data related to seismicity, deformation, and gas emissions.

In order to provide a simple and automated way of assessing the evolution of the volcanic system from looking at the monitoring signals, the ST-HASSET was developed (Sobradelo and Martí, 2015; Bartolini et al., 2016). This etool offers an alternative to the BET-EF (Marzocchi et al., 2008) and BET-UNREST (Tonini et al., 2016) and also proposes a flexible probabilistic approach to incorporate monitoring information for the quantification of short-term volcanic hazard that looks for significant changes in the values of the measured unrest indicators, across consecutive time intervals. In comparison to the BET-EF and BET-UNREST, ST-HASSET does not focus on the absolute value of each variable with respect to a defined threshold, but compares its degree of change with respect to the previous time interval. In each case, a variation that is considered significant can be defined in advance given the specific characteristics of the volcano being studied.

Assuming that geophysical indicators such as seismicity and ground deformation provide insights on the location of magma during the unrest phase (Endo and Murray, 1991; Chouet, 1996; McNutt, 1996; Martí et el., 2013), changes in the location of such unrest parameters may indicate magma movement and, consequently, that the location of potential new vents may also change. This is extremely important when conducting hazard assessment analysis, as the location of the eruptive vent may condition the resulting hazards and their potential impacts. In this sense, short-term hazard assessment needs to inform in real time on how monitoring information changes the probabilities of vent opening (volcanic susceptibility) and of the hazards that may occur, as well as of the proximity of the eruptive event.

In order to show how ST-HASSET works, we apply it retrospectively to the unrest episode that preceded the El Hierro eruption in 2011. When volcanic unrest started here in July 2011, the Spanish National Geographical Institute (IGN), the institution responsible for volcano monitoring in Spain, set up a dense seismic monitoring network composed of a threecomponent (3CC) broadband station (CTIG) and eight shortand medium-period (natural periods of 1 and $5 \mathrm{~s}$ ) 3CC stations (López et al., 2012) (Fig. 1). In order to monitor the associated 3-D deformation, the IGN also deployed four extra GPS stations on El Hierro to reinforce the capacity of the single pre-existing GPS station (FRON) (Fig. 1) belong-

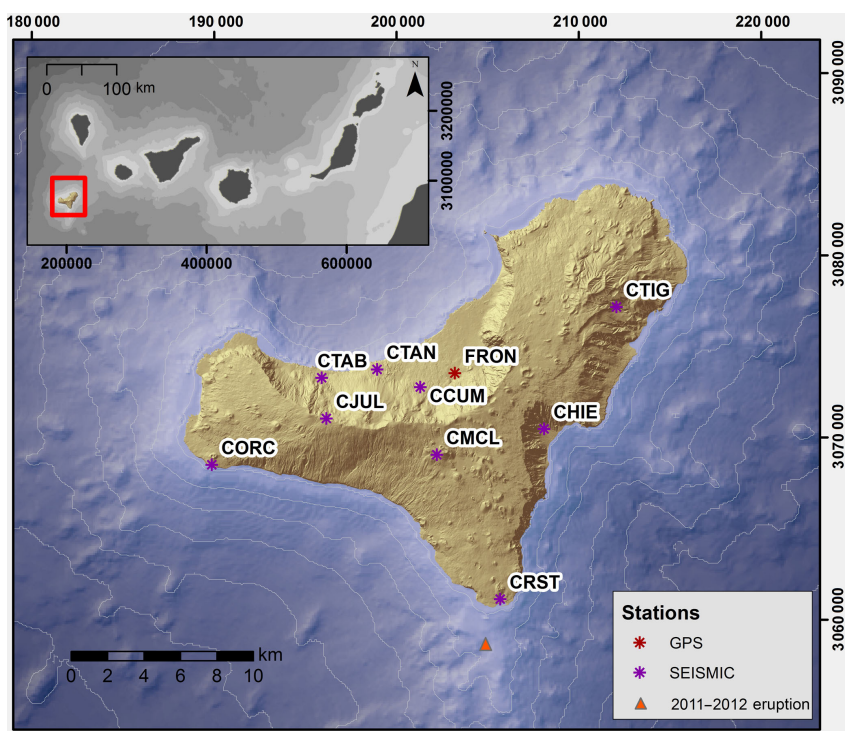

Figure 1. IGN monitoring network during the unrest period at El Hierro. The top left inset displays the location of El Hierro within the Canary Archipelago.

ing to the Canarian regional government (López et al., 2012, 2014; Martí et al., 2013). The amount of information registered provides a good example of a monitored unrest episode with a complete dataset. However, during the pre-eruptive unrest phase the continuous changes in the position of the seismicity and deformation sources made it all but impossible to forecast the position of the new vent and, consequently, to define reliable eruption scenarios.

The objective of this retrospective analysis is to define guidelines on how we can manage the information generated by a monitoring network during the unrest phase of an ongoing crisis. We use the data recorded in the pre-eruptive unrest episode that took place on El Hierro in 2011 to update in real time the spatial probability of the new vent opening and to interpret the unrest precursors as a means of determining the probability of evolution of these indicators. So, we first evaluate the volcanic susceptibility combining the real-time monitoring information with the QVAST tool (Bartolini et al., 2013), which provides a real-time variation of the vent opening probabilities. Then, we combine each updated result with the ST-HASSET tool to determine the evolution over time of the unrest indicators. The results obtained allow us to realize how the application of these tools helps interpret the unrest indicators and how they can be used for improving the susceptibility assessment and the definition of realistic eruptive scenarios, thus facilitating the decision-making process and the management of the volcanic crisis. 


\section{Methodology}

The methodology used in this study basically consists in the systematic application of two e-tools specifically designed for conducting probabilistic spatial and temporal analysis in volcanic hazard assessment.

QVAST (Bartolini et al., 2013) is a tool that has been developed to evaluate the spatial probability of a new vent opening (volcanic susceptibility) using volcano-structural data and seismicity. In monogenetic volcanism, as it is the case of El Hierro, each new eruption creates a different vent, which indicates that accurate spatial forecasting is highly uncertain. This type of analysis has been often applied in long-term hazard assessment as it represents a good starting point for developing hazard maps based on certain assumptions: (i) future eruptive vents will be close to the previous ones and (ii) the stress field plays the most significant role in determining where magma will reach the surface (see Martí et al., 2016). The result is a (long-term) susceptibility map obtained by assigning different weights to each of the probability density functions in each dataset (volcano-structural elements: location of past vents, eruptive fissures, fractures, faults, dykes, etc.) considered in the analysis, which are combined via a weighted sum and modeled in a non-homogeneous Poisson process. During an unrest phase, the (short-term) susceptibility map varies as new information (e.g., the location of the seismic events) is provided by monitoring data. Hence, the previously defined probabilities of hosting a new vent will change in terms of where the new seismicity and/or ground deformation is located - assuming that both parameters provide an indication of magma movement and location.

The probability of occurrence of a possible eruptive scenario will change according to the variations in the shortterm susceptibility map, which will be redefined each time that new monitoring information will be computed; thus, we also have to calculate the temporal evolution of monitoring data.

The ST-HASSET tool (Sobradelo and Martí, 2015; Bartolini et al., 2016) is a simple tool that develops an event tree structure that uses a quantitative approach via Bayesian inference to assess the hazard of a particular volcanic scenario by taking into account monitoring data and all relevant data pertaining to the past history of the volcano. Indicators are shown on a common probability scale to visualize their progress during the unrest phase and to estimate the probability of occurrence of a particular eruptive scenario.

\section{Unrest on El Hierro in 2011}

El Hierro, situated in the southwestern corner of the Canary archipelago (Fig. 1), is geologically the youngest of these islands and its oldest subaerial rocks have been dated at 1.12 Ma (Guillou et al., 1996). It corresponds to a shield structure formed by different volcanic edifices with three rift zones along which recent volcanism has been concentrated (Guillou et al., 1996). The studied unrest period started on 19 July 2011 and gave rise to a submarine eruption that started on 10 October 2011 (Fig. 1). The whole episode was well monitored by the IGN and, during the period leading up to the eruption, approximately 10000 earthquakes with local magnitudes of up to 4.3 were recorded, and over $5 \mathrm{~cm}$ of vertical and horizontal surface deformations was registered (López et al., 2014).

This pre-eruptive unrest started with a marked increase in seismicity, followed a few days later by surface deformation and gas emissions (López et al., 2012; Domínguez Cerdeña et al., 2014). The evolution of the seismicity during this episode was characterized by changes in the hypocentral location that were interpreted as movements in the position of the magma (Fig. 2 and Table 1) (López et al., 2012, 2014). During the first weeks of unrest, all the seismic events were located in the north of the island at a depth of about $10-15 \mathrm{~km}$ b.s.l. and were of low magnitude. As of 4-26 September 2011, the seismicity migrated southwards along the crust-mantle boundary and the amount of released seismic energy increased. GPS stations translated towards north, suggesting a simultaneous surface deformation pattern that reflected a correlated migration of the pressure source towards the south. From 27 September to 7 October 2011, both the seismic rate and the seismic energy grew and events were now located mostly off the SW coast of El Hierro. At the same time, a sudden deflation-reinflation was observed on the N-S component at all GPS stations (1-5 October 2011). On 8 October at 20:34 (GMT), a $4.3 M_{L}$ earthquake (the greatest magnitude recorded during the unrest period) occurred $1.5 \mathrm{~km}$ off the $\mathrm{SW}$ coast of the island at a depth of $12 \mathrm{~km}$. However, from this moment onwards, very few further earthquakes were registered and the pre-eruptive episode culminated with a submarine eruption on the southern flank of the island's volcanic edifice (López et al., 2012) (Fig. 1). On 10 October at 04:10 UTC, a clear emergent tremor signal was registered by all the seismic stations indicating the onset of the eruptive activity that lasted for more than 4 months (until the end of February 2012) (López et al., 2014).

\section{Datasets}

\subsection{Spatial analysis}

A susceptibility analysis enables us to determine the probability of occurrence of future eruptive vents. This probability depends on the volcano-structural elements that define the structural setting of a volcano and the past pathways taken by the magma as it ascended to the Earth's surface. Eruptive vents and fissures, dykes, faults, fumaroles, and the stress field are the most important elements (Martin et al., 2004; Jaquet et al., 2008; Cappello et al., 2012; Bartolini et al., 2013; 
Table 1. Indicators during the unrest period. NA indicates not available.

\begin{tabular}{|c|c|c|c|c|c|c|c|c|c|c|c|c|}
\hline $\begin{array}{l}\text { Unrest } \\
\text { indicators }\end{array}$ & & $\begin{array}{r}\text { Seismici } \\
\text { increas }\end{array}$ & & & $\begin{array}{l}\text { RSAM } \\
\text { acceleration } \\
\text { increase }\end{array}$ & & & $\begin{array}{c}\text { Accumulated } \\
\text { energy } \\
\text { released } \\
\text { increase }\end{array}$ & & & $\begin{array}{r}\text { Lateral } \\
\text { migratio } \\
\text { of seismic }\end{array}$ & \\
\hline & $\mathrm{Y} / \mathrm{N} / \mathrm{NA}$ & $\begin{array}{l}\text { Value } \\
\text { (no.) }\end{array}$ & Probability & $\mathrm{Y} / \mathrm{N} / \mathrm{NA}$ & $\begin{array}{r}\text { Value } \\
\text { (1/RSAM unit) }\end{array}$ & Probability & $\mathrm{Y} / \mathrm{N} / \mathrm{NA}$ & $\begin{array}{r}\text { Value } \\
(\mathrm{J})\end{array}$ & Probability & $\mathrm{Y} / \mathrm{N} / \mathrm{NA}$ & (Fig. 2) & Probability \\
\hline 2011-07-19 & $\mathrm{N}$ & 0 & 0.333 & $\mathrm{~N}$ & 0.041 & 0.333 & $\mathrm{~N}$ & $5.80 \mathrm{E}+07$ & 0.333 & $\mathrm{~N}$ & & 0.333 \\
\hline $2011-07-20$ & $\mathrm{~N}$ & 0 & 0.25 & $\mathrm{~N}$ & 0.042 & 0.250 & Y & $2.41 \mathrm{E}+08$ & 0.500 & Y & & 0.500 \\
\hline 2011-07-21 & $\mathrm{N}$ & 0 & 0.2 & $\mathrm{~N}$ & 0.039 & 0.200 & $\mathrm{Y}$ & $1.72 \mathrm{E}+09$ & 0.600 & $\mathrm{~N}$ & & 0.400 \\
\hline $2011-07-22$ & $\mathrm{~N}$ & 0 & 0.167 & $\mathrm{~N}$ & 0.043 & 0.167 & $\mathrm{Y}$ & $3.18 \mathrm{E}+09$ & 0.667 & $\mathrm{~N}$ & & 0.333 \\
\hline $2011-07-23$ & $\mathrm{~N}$ & 0 & 0.143 & $\mathrm{~N}$ & 0.047 & 0.143 & $\mathrm{Y}$ & $2.15 \mathrm{E}+09$ & 0.715 & $\mathrm{Y}$ & & 0.428 \\
\hline $2011-07-24$ & $\mathrm{~N}$ & 0 & 0.125 & $\mathrm{~N}$ & 0.051 & 0.125 & Y & $4.30 \mathrm{E}+08$ & 0.751 & Y & & 0.499 \\
\hline $2011-07-25$ & $\mathrm{~N}$ & 0 & 0.111 & $\mathrm{~N}$ & 0.054 & 0.111 & $\mathrm{Y}$ & $5.73 \mathrm{E}+08$ & 0.779 & Y & & 0.555 \\
\hline $2011-07-26$ & $\mathrm{~N}$ & 0 & 0.1 & $\mathrm{~N}$ & 0.053 & 0.100 & $\mathrm{Y}$ & $1.50 \mathrm{E}+09$ & 0.801 & $\mathrm{~N}$ & & 0.499 \\
\hline $2011-07-27$ & $\mathrm{Y}$ & 2 & 0.182 & $\mathrm{~N}$ & 0.052 & 0.091 & Y & $3.00 \mathrm{E}+09$ & 0.819 & $\mathrm{~N}$ & & 0.454 \\
\hline 2011-07-28 & $\mathrm{N}$ & 0 & 0.167 & Y & 0.055 & 0.167 & $\mathrm{Y}$ & $7.27 \mathrm{E}+08$ & 0.834 & $\mathrm{~N}$ & & 0.416 \\
\hline 2011-07-29 & $\mathrm{N}$ & 0 & 0.154 & $\mathrm{Y}$ & 0.044 & 0.231 & $\mathrm{~N}$ & $1.79 \mathrm{E}+08$ & 0.770 & $\mathrm{~N}$ & & 0.384 \\
\hline $2011-07-30$ & $\mathrm{~N}$ & 0 & 0.143 & $\mathrm{Y}$ & 0.036 & 0.286 & $\mathrm{~N}$ & $6.17 \mathrm{E}+08$ & 0.715 & $\mathrm{~N}$ & & 0.357 \\
\hline $2011-07-31$ & $\mathrm{~N}$ & 0 & 0.133 & $\mathrm{~N}$ & 0.035 & 0.267 & $\mathrm{~N}$ & $1.22 \mathrm{E}+09$ & 0.667 & $\mathrm{~N}$ & & 0.333 \\
\hline 2011-08-01 & $\mathrm{N}$ & 0 & 0.125 & $\mathrm{~N}$ & 0.039 & 0.250 & $\mathrm{~N}$ & $1.75 \mathrm{E}+08$ & 0.625 & $\mathrm{~N}$ & & 0.312 \\
\hline 2011-08-02 & $\mathrm{N}$ & 0 & 0.118 & $\mathrm{~N}$ & 0.047 & 0.235 & $\mathrm{~N}$ & $4.60 \mathrm{E}+08$ & 0.588 & Y & & 0.352 \\
\hline 2011-08-03 & $\mathrm{N}$ & 0 & 0.111 & $\mathrm{~N}$ & 0.045 & 0.222 & $\mathrm{~N}$ & $4.48 \mathrm{E}+08$ & 0.555 & $\mathrm{Y}$ & & 0.388 \\
\hline 2011-08-04 & $\mathrm{N}$ & 0 & 0.105 & $\mathrm{~N}$ & 0.042 & 0.210 & Y & $2.60 \mathrm{E}+09$ & 0.578 & Y & & 0.420 \\
\hline $2011-08-05$ & $\mathrm{~N}$ & 0 & 0.1 & $\mathrm{~N}$ & 0.038 & 0.199 & $\mathrm{Y}$ & $4.24 \mathrm{E}+09$ & 0.599 & $\mathrm{Y}$ & & 0.449 \\
\hline $2011-08-06$ & $\mathrm{~N}$ & 0 & $\begin{array}{r}0.1 \\
0.095\end{array}$ & $\mathrm{~N}$ & 0.041 & $\begin{array}{l}0.190 \\
0.190\end{array}$ & $\mathrm{Y}$ & $2.31 \mathrm{E}+08$ & 0.618 & $\mathrm{Y}$ & & 0.475 \\
\hline $2011-08-07$ & $\mathrm{~N}$ & 0 & 0.091 & $\mathrm{~N}$ & 0.056 & 0.181 & $\mathrm{Y}$ & $1.62 \mathrm{E}+09$ & 0.635 & $\mathrm{~N}$ & & 0.453 \\
\hline 2011-08-08 & $\mathrm{N}$ & 0 & 0.087 & Y & 0.066 & 0.217 & $\mathrm{~N}$ & $1.46 \mathrm{E}+09$ & 0.607 & $\mathrm{~N}$ & & 0.433 \\
\hline 2011-08-09 & $\mathrm{Y}$ & 1 & 0.125 & $\mathrm{Y}$ & 0.053 & 0.250 & Y & $4.38 \mathrm{E}+09$ & 0.623 & $\mathrm{~N}$ & & 0.415 \\
\hline 2011-08-10 & $\mathrm{N}$ & 0 & 0.12 & $\mathrm{Y}$ & 0.037 & 0.280 & $\mathrm{Y}$ & $1.58 \mathrm{E}+09$ & 0.638 & $\mathrm{~N}$ & & 0.398 \\
\hline 2011-08-11 & $\mathrm{N}$ & 0 & 0.115 & $\mathrm{~N}$ & 0.035 & 0.269 & $\mathrm{~N}$ & $4.12 \mathrm{E}+08$ & 0.613 & $\mathrm{~N}$ & & 0.383 \\
\hline $2011-08-12$ & $\mathrm{~N}$ & 0 & 0.111 & $\mathrm{~N}$ & 0.037 & 0.259 & $\mathrm{~N}$ & $2.72 \mathrm{E}+08$ & 0.590 & $\mathrm{~N}$ & & 0.369 \\
\hline 2011-08-13 & $\mathrm{N}$ & 0 & 0.107 & $\mathrm{~N}$ & 0.036 & 0.250 & $\mathrm{~N}$ & $6.22 \mathrm{E}+07$ & 0.569 & Y & & 0.392 \\
\hline 2011-08-14 & $\mathrm{N}$ & 0 & 0.103 & $\mathrm{~N}$ & 0.035 & 0.241 & $\mathrm{~N}$ & $1.40 \mathrm{E}+09$ & 0.549 & Y & & 0.413 \\
\hline 2011-08-15 & $\mathrm{N}$ & 0 & 0.1 & $\mathrm{~N}$ & 0.038 & 0.233 & $\mathrm{~N}$ & $6.61 \mathrm{E}+08$ & 0.531 & $\mathrm{~N}$ & & 0.399 \\
\hline 2011-08-16 & $\mathrm{N}$ & 0 & 0.097 & $\mathrm{~N}$ & 0.041 & 0.225 & $\mathrm{~N}$ & $1.73 E+08$ & 0.514 & $\mathrm{Y}$ & & 0.418 \\
\hline 2011-08-17 & $\mathrm{N}$ & 0 & 0.094 & $\mathrm{~N}$ & 0.035 & 0.218 & $\mathrm{~N}$ & $6.48 \mathrm{E}+07$ & 0.498 & $\mathrm{Y}$ & & 0.436 \\
\hline 2011-08-18 & $\mathrm{N}$ & 0 & 0.091 & $\mathrm{~N}$ & 0.044 & 0.211 & $\mathrm{~N}$ & $4.55 \mathrm{E}+09$ & 0.483 & $\mathrm{Y}$ & & 0.453 \\
\hline 2011-08-19 & $\mathrm{N}$ & 0 & 0.088 & $\mathrm{~N}$ & 0.057 & 0.205 & Y & $2.16 \mathrm{E}+09$ & 0.498 & Y & & 0.469 \\
\hline $2011-08-20$ & $\mathrm{~N}$ & 0 & 0.085 & Y & 0.065 & 0.228 & $\mathrm{~N}$ & $1.75 \mathrm{E}+08$ & 0.484 & $\mathrm{~N}$ & & 0.456 \\
\hline $2011-08-21$ & $\mathrm{~N}$ & 0 & 0.083 & $\mathrm{Y}$ & 0.055 & 0.249 & $\mathrm{~N}$ & $2.25 \mathrm{E}+09$ & 0.471 & $\mathrm{~N}$ & & 0.443 \\
\hline 2011-08-22 & $\mathrm{N}$ & 0 & 0.081 & Y & 0.044 & 0.269 & $\mathrm{~N}$ & $2.72 \mathrm{E}+09$ & 0.458 & Y & & 0.458 \\
\hline 2011-08-23 & $\mathrm{N}$ & 0 & 0.079 & Y & 0.040 & 0.288 & $\mathrm{~N}$ & $1.11 \mathrm{E}+09$ & 0.446 & $\mathrm{Y}$ & & 0.472 \\
\hline 2011-08-24 & $\mathrm{N}$ & 0 & 0.077 & $\mathrm{~N}$ & 0.041 & 0.281 & $\mathrm{~N}$ & $3.55 \mathrm{E}+07$ & 0.435 & $\mathrm{~N}$ & & 0.460 \\
\hline $2011-08-25$ & $\mathrm{~N}$ & 0 & 0.075 & $\mathrm{~N}$ & 0.051 & 0.274 & $\mathrm{~N}$ & $2.55 \mathrm{E}+08$ & 0.424 & $\mathrm{~N}$ & & 0.449 \\
\hline $2011-08-26$ & $\mathrm{~N}$ & 0 & 0.073 & $\mathrm{~N}$ & 0.058 & 0.267 & $\mathrm{~N}$ & $5.73 \mathrm{E}+07$ & 0.414 & $\mathrm{Y}$ & & 0.462 \\
\hline $2011-08-27$ & $\mathrm{~N}$ & 0 & 0.071 & Y & 0.062 & 0.284 & $\mathrm{~N}$ & $1.17 \mathrm{E}+08$ & 0.404 & $\mathrm{~N}$ & & 0.451 \\
\hline $2011-08-28$ & $\mathrm{~N}$ & 0 & 0.069 & $\mathrm{Y}$ & 0.057 & 0.301 & $\mathrm{~N}$ & $2.56 \mathrm{E}+07$ & 0.395 & $\mathrm{~N}$ & & 0.441 \\
\hline 2011-08-29 & $\mathrm{N}$ & 0 & 0.067 & Y & 0.041 & 0.317 & $\mathrm{~N}$ & $2.42 \mathrm{E}+08$ & 0.386 & $\mathrm{~N}$ & & 0.431 \\
\hline 2011-08-30 & $\mathrm{N}$ & 0 & 0.066 & $\mathrm{~N}$ & 0.049 & 0.310 & $\mathrm{~N}$ & $8.00 \mathrm{E}+08$ & 0.377 & $\mathrm{~N}$ & & 0.421 \\
\hline 2011-08-31 & $\mathrm{N}$ & 0 & 0.065 & $\mathrm{~N}$ & 0.084 & 0.303 & $\mathrm{~N}$ & $7.45 \mathrm{E}+08$ & 0.369 & $\mathrm{~N}$ & & 0.412 \\
\hline $2011-09-01$ & $\mathrm{Y}$ & 1 & 0.085 & $\mathrm{Y}$ & 0.122 & 0.318 & $\mathrm{~N}$ & $4.35 \mathrm{E}+09$ & 0.361 & $\mathrm{~N}$ & & 0.403 \\
\hline 2011-09-02 & $\mathrm{Y}$ & 2 & 0.104 & Y & 0.090 & 0.332 & $\mathrm{~N}$ & $3.96 \mathrm{E}+09$ & 0.353 & $\mathrm{~N}$ & & 0.395 \\
\hline 2011-09-03 & $\mathrm{N}$ & 0 & 0.102 & Y & 0.060 & 0.346 & $\mathrm{~N}$ & $1.28 \mathrm{E}+09$ & 0.346 & $\mathrm{~N}$ & & 0.387 \\
\hline 2011-09-04 & $\mathrm{N}$ & 0 & 0.1 & $\mathrm{Y}$ & 0.054 & 0.359 & $\mathrm{~N}$ & $8.43 \mathrm{E}+08$ & 0.339 & Y & & 0.399 \\
\hline 2011-09-05 & $\mathrm{N}$ & 0 & 0.098 & $\mathrm{~N}$ & 0.054 & 0.352 & $\mathrm{~N}$ & $5.58 \mathrm{E}+08$ & 0.332 & Y & & 0.411 \\
\hline 2011-09-06 & $\mathrm{N}$ & 0 & 0.096 & $\mathrm{~N}$ & 0.049 & 0.345 & $\mathrm{~N}$ & $7.45 \mathrm{E}+08$ & 0.326 & $\mathrm{~N}$ & & 0.403 \\
\hline 2011-09-07 & $\mathrm{N}$ & 0 & 0.094 & $\mathrm{~N}$ & 0.055 & 0.338 & $\mathrm{~N}$ & $1.40 \mathrm{E}+09$ & 0.320 & $\mathrm{~N}$ & & 0.395 \\
\hline $2011-09-08$ & $\mathrm{~N}$ & 0 & 0.092 & $\mathrm{Y}$ & 0.063 & 0.350 & $\mathrm{~N}$ & $9.15 \mathrm{E}+08$ & 0.314 & $\mathrm{~N}$ & & 0.388 \\
\hline $2011-09-09$ & $\mathrm{~N}$ & 0 & $\begin{array}{r}0.092 \\
0.09\end{array}$ & $\mathrm{Y}$ & $\begin{array}{l}0.056 \\
0.056\end{array}$ & 0.362 & $\mathrm{~N}$ & $1.60 \mathrm{E}+09$ & 0.308 & $\mathrm{~N}$ & & 0.381 \\
\hline 2011-09-10 & Y & 1 & 0.106 & Y & 0.047 & 0.373 & $\mathrm{~N}$ & $1.88 \mathrm{E}+09$ & 0.303 & $\mathrm{~N}$ & & 0.374 \\
\hline 2011-09-11 & $\mathrm{N}$ & 0 & 0.104 & $\mathrm{~N}$ & 0.051 & 0.366 & $\mathrm{~N}$ & $6.27 \mathrm{E}+08$ & 0.298 & $\mathrm{~N}$ & & 0.367 \\
\hline 2011-09-12 & Y & 3 & 0.119 & $\mathrm{~N}$ & 0.051 & 0.360 & $\mathrm{~N}$ & $3.87 \mathrm{E}+09$ & 0.293 & $\mathrm{~N}$ & & 0.361 \\
\hline 2011-09-13 & $\mathrm{N}$ & 1 & 0.117 & $\mathrm{~N}$ & 0.045 & 0.354 & $\mathrm{~N}$ & $2.34 \mathrm{E}+09$ & 0.288 & $\mathrm{~N}$ & & 0.355 \\
\hline $2011-09-14$ & $\mathrm{~N}$ & 0 & 0.115 & $\mathrm{~N}$ & 0.050 & 0.348 & $\mathrm{~N}$ & $7.86 \mathrm{E}+08$ & 0.283 & $\mathrm{~N}$ & & 0.349 \\
\hline 2011-09-15 & $\mathrm{N}$ & 0 & 0.113 & $\mathrm{~N}$ & 0.059 & 0.342 & $\mathrm{~N}$ & $9.42 \mathrm{E}+08$ & 0.278 & Y & & 0.360 \\
\hline 2011-09-16 & $\mathrm{N}$ & 0 & 0.111 & Y & 0.061 & 0.353 & $\mathrm{~N}$ & $4.77 \mathrm{E}+08$ & 0.274 & $\mathrm{~N}$ & & 0.354 \\
\hline $2011-09-17$ & $\mathrm{~N}$ & 0 & 0.109 & $\mathrm{Y}$ & 0.050 & 0.363 & $\mathrm{~N}$ & $5.50 \mathrm{E}+08$ & 0.270 & $\mathrm{~N}$ & & 0.348 \\
\hline 2011-09-18 & $\mathrm{N}$ & 0 & 0.107 & Y & 0.041 & 0.373 & $\mathrm{~N}$ & $1.06 \mathrm{E}+09$ & 0.266 & $\mathrm{~N}$ & & 0.343 \\
\hline 2011-09-19 & $\mathrm{N}$ & 0 & 0.105 & $\mathrm{Y}$ & 0.039 & 0.383 & $\mathrm{~N}$ & $5.71 \mathrm{E}+08$ & 0.262 & $\mathrm{~N}$ & & 0.338 \\
\hline 2011-09-20 & $\mathrm{Y}$ & 8 & 0.119 & $\mathrm{Y}$ & 0.035 & 0.392 & $\mathrm{~N}$ & $8.51 \mathrm{E}+09$ & 0.258 & $\mathrm{~N}$ & & 0.333 \\
\hline $2011-09-21$ & $\mathrm{~N}$ & 2 & 0.117 & $\mathrm{~N}$ & 0.037 & 0.386 & $\mathrm{~N}$ & $1.69 \mathrm{E}+09$ & 0.254 & $\mathrm{~N}$ & & 0.328 \\
\hline $2011-09-22$ & $\mathrm{~N}$ & 1 & 0.11 & $\mathrm{~N}$ & 0.037 & 0.380 & $\mathrm{~N}$ & $3.76 \mathrm{E}+09$ & 0.250 & $\mathrm{~N}$ & & 0.323 \\
\hline $2011-09-23$ & Y & 6 & 0.128 & $\mathrm{~N}$ & 0.040 & 0.374 & $\mathrm{~N}$ & $9.38 \mathrm{E}+09$ & 0.246 & $\mathrm{~N}$ & & 0.318 \\
\hline $2011-09-24$ & $\mathrm{~N}$ & 2 & 0.126 & $\mathrm{~N}$ & 0.043 & 0.369 & $\mathrm{Y}$ & $1.19 \mathrm{E}+10$ & 0.257 & $\mathrm{~N}$ & & 0.313 \\
\hline $2011-09-25$ & $\mathrm{~N}$ & 2 & 0.12 & $\mathrm{~N}$ & 0.065 & 0.3 & Y & $3.57 \mathrm{E}+09$ & 0.267 & $\mathrm{~N}$ & & 0.309 \\
\hline 2011-09-26 & $\mathrm{Y}$ & 11 & 0.136 & $\mathrm{Y}$ & 0.073 & 0.373 & Y & $1.21 \mathrm{E}+10$ & 0.277 & $\mathrm{~N}$ & & 0.305 \\
\hline 2011-09-27 & $\mathrm{Y}$ & 48 & 0.148 & $\mathrm{Y}$ & 0.041 & 0.382 & $\mathrm{Y}$ & $1.24 \mathrm{E}+11$ & 0.287 & Y & & 0.315 \\
\hline $2011-09-28$ & $\mathrm{Y}$ & 66 & 0.16 & Y & 0.039 & 0.390 & $\mathrm{Y}$ & $1.17 \mathrm{E}+11$ & 0.297 & $\mathrm{Y}$ & & 0.324 \\
\hline 2011-09-29 & $\mathrm{Y}$ & 49 & 0.171 & Y & 0.032 & 0.398 & $\mathrm{Y}$ & $1.57 \mathrm{E}+11$ & 0.306 & $\mathrm{Y}$ & & 0.333 \\
\hline $2011-09-30$ & $\mathrm{~N}$ & 21 & 0.169 & $\mathrm{~N}$ & 0.053 & 0.393 & $\mathrm{Y}$ & $3.21 \mathrm{E}+10$ & 0.315 & $\mathrm{Y}$ & & 0.342 \\
\hline $2011-10-01$ & $\mathrm{~N}$ & 27 & 0.16 & $\mathrm{~N}$ & 0.064 & 0.38 & $\mathrm{Y}$ & $8.91 \mathrm{E}+10$ & 0.3 & $\mathrm{Y}$ & & 0.3 \\
\hline $2011-10-02$ & Y & 34 & 0.1 & $\mathrm{~N}$ & & & Y & $6.85 \mathrm{E}+1$ & 0.3 & $\mathrm{~N}$ & & 0.34 \\
\hline $2011-10-03$ & $\mathrm{Y}$ & 44 & 0.188 & $\mathrm{~N}$ & 0.051 & 0.378 & $\mathrm{Y}$ & $9.37 \mathrm{E}+10$ & 0.341 & $\mathrm{Y}$ & & 0.354 \\
\hline 2011-10-04 & $\mathrm{N}$ & 17 & 0.186 & Y & 0.060 & 0.386 & $\mathrm{Y}$ & $4.76 \mathrm{E}+10$ & 0.349 & $\mathrm{Y}$ & & 0.362 \\
\hline $2011-10-05$ & $\mathrm{~N}$ & 6 & 0.184 & $\mathrm{Y}$ & 0.051 & 0.394 & $\mathrm{~N}$ & $2.63 \mathrm{E}+10$ & 0.345 & $\mathrm{Y}$ & & 0.370 \\
\hline $2011-10-06$ & $\mathrm{Y}$ & 34 & $\begin{array}{l}0.184 \\
0.194\end{array}$ & $\begin{array}{l}1 \\
Y\end{array}$ & $\begin{array}{l}0.040 \\
0.040\end{array}$ & 0.401 & $\mathrm{~N}$ & $3.99 \mathrm{E}+10$ & 0.341 & Y & & 0.378 \\
\hline $2011-10-07$ & Y & 27 & 0.204 & Y & 0.023 & 0.408 & $\mathrm{Y}$ & $1.18 \mathrm{E}+11$ & 0.349 & Y & & 0.385 \\
\hline $2011-10-08$ & $\mathrm{~N}$ & 12 & 0.20 & $\mathrm{Y}$ & & & $\mathrm{Y}$ & & & $\mathrm{Y}$ & & \\
\hline $2011-10-09$ & $\mathrm{~N}$ & 3 & $\begin{array}{r}0.202 \\
0.2\end{array}$ & $\mathrm{Y}$ & 0.039 & 0.422 & $\mathrm{Y}$ & $1.95 \mathrm{E}+10$ & 0.365 & Y & & 0.399 \\
\hline 2011-10-10 & $\mathrm{N}$ & 2 & 0.198 & $\mathrm{Y}$ & 0.004 & 0.429 & $\mathrm{~N}$ & $2.00 \mathrm{E}+09$ & 0.361 & $\mathrm{~N}$ & & 0.394 \\
\hline
\end{tabular}

and references therein) that determine the probabilities of an eruptive vent opening in an area that was affected by similar types of eruptions in the past.

In order to compute the probability of opening a new eruptive vent at El Hierro, we took into account the most relevant volcano-structural data as given by Becerril et al. (2013, 2014) (Fig. 2): (i) the subaerial vents and eruptive fissures that are part of the rift volcanism (including sub-recent and recent eruptions) and (ii) the submarine vents and eruptive fissures deduced from bathymetric inference. Furthermore, we chose only those eruptive fissures oriented between $\mathrm{N} 00^{\circ} \mathrm{E}$ and $\mathrm{N} 45^{\circ} \mathrm{E}$ in relation to the orientation of the regional stress field (see Geyer et al., 2016). We assumed that the stress field plays the most important role in determining where the magma will reach the surface and the fractures 


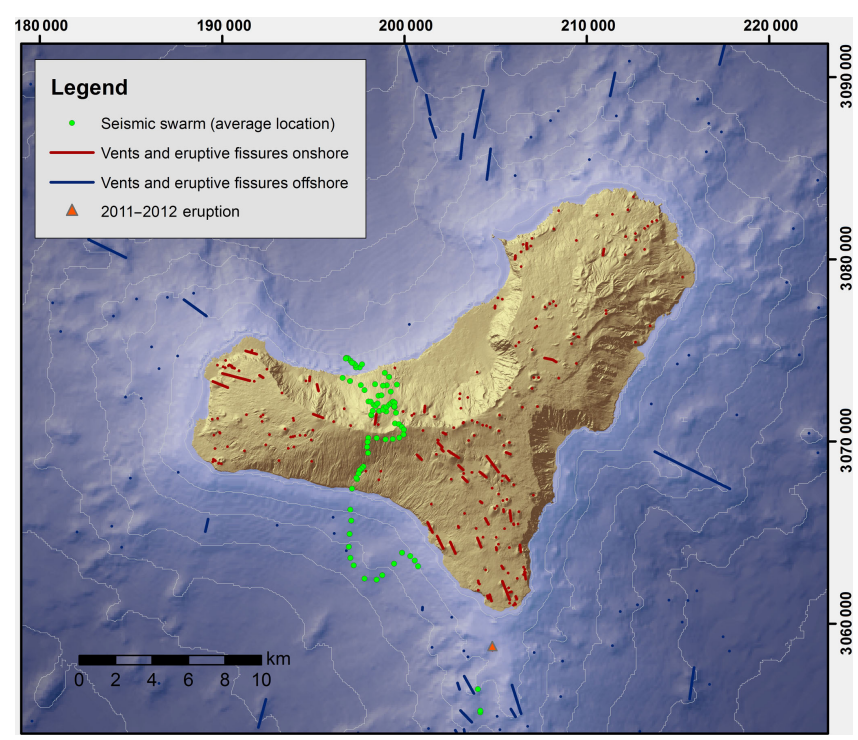

Figure 2. Structural data of El Hierro (vents and fissure onshore and offshore, as in Becerril et al., 2013, 2014) and the evolution of the seismicity during the unrest period (average location of the seismic swarm).

orientated in this direction were those that offered the least resistance to magma transport.

To conduct the short-term analysis, we complemented the previous dataset with the addition of data on the evolution of the seismicity for the unrest period (19 July-10 October 2011).

We assumed that in this short-term spatial analysis the location of the seismicity reflected the position of the magma, as it provides a good indicator for tracking magma migration and for determining where it may potentially reach the surface. However, the location of gas emission was not considered in this short-term analysis as they were too disperse in the whole area (López et al., 2012) and thus not sufficiently informative on the position that magma could have below the island. Concerning the surface deformation, we considered this parameter only in the temporal analysis due to the lack of a well-distributed ground deformation monitoring network operating during the El Hierro unrest episode. So, as described in López et al. (2012), the highest values of uplift were found in the area where the seismicity moved from north to south and where no GPS was available.

Seismic data were obtained from the seismic catalogue published by IGN (http://www.ign.es, last access: 4 June 2018) (Fig. 2). Data were grouped in time windows of 4 days to optimize the forecast given that certain volcanic systems have indicated that magmatic processes have a memory with a timescale of just a few days (Connor et al., 2003; Jaquet and Carniel, 2003; Jaquet et al., 2006; Tárraga et al., 2006; Carniel et al., 2006). Such a selection allows assuring the persistent behaviors of the system. Within the time window, the seismic activity will follow the same trend of previous days, allowing the short-term forecast. We selected from the IGN catalogue only those earthquakes of magnitudes greater than zero and precise locations, with epicenter maximum semi-ellipse axes of less than $15 \mathrm{~km}$, minimum semi-ellipse axes of less than $6 \mathrm{~km}$, and a depth error of less than $8 \mathrm{~km}$. In this way, we aimed to avoid - inasmuch as was possible - errors in the hypocenter localization of earthquakes due to the small number of the seismic stations in place during the first unrest phase.

\subsection{Temporal analysis}

The data for the temporal analysis consisted of observables whose relative variation with time may indicate changes in the processes occurring inside the volcano when preparing for a new eruption (Sobradelo and Martí, 2015; Bartolini et al., 2016). In our methodology, we do not use the absolute values of each parameter, but considering their relative variation with time, we only indicate whether there is an increase or a decrease in the value of such parameter in each time interval. We used the monitoring data gathered by the IGN and other published information (López et al., 2012, 2014; Martí et al., 2013; Telesca et al., 2014). This information is given in Table 1 and includes

- the number of seismic events

- RSAM (Real-time Seismic Amplitude Measurement)

- the seismic energy released during the fracturing process

- the lateral and vertical migration of the seismicity

- the number of shallow seismic events

- the strain variation.

Therefore, consistent with the choices adopted for the spatial analysis, the variation in the unrest indicators (increase or decrease) was evaluated in relation to the mean values for the previous 4 days. The seismic rate variation was considered by taking into account only those events with a magnitude over 2.5 (greater than the completeness magnitude during almost all the period), assuring this way the study of the seismic evolution (López et al., 2017), while a significant change was considered only when the rate of variation was $25 \%$ higher in relation to the previous 4 days as a consequence of stress reorganization (Stein, 1999). RSAM data were obtained by analyzing the signal registered by the vertical component of the seismic broadband CTIG station (Fig. 1). Although the signal may have a high background of seismic noise, a RSAM increase is a good indicator of the transport of the magma to the surface (Endo and Murray, 1991). In order to highlight a significant increase in RSAM values, we considered the variation in the slope of the inverse of the RSAM, which is clear evidence of a consistent increase in the signal. The accumulated increase in energy release was considered 
to be significant when the energy value (i.e., the accumulated value in relation to the mean value over the last 4 days) was greater than $10 \%$. In this case, the accumulated energy curve showed a notable slope variation. For the lateral migration of the seismicity, we considered a significant variation to exist when the displacement increment was over $1 \mathrm{~km}$. This is compatible with the effects on hazard scenarios when the vent location changes. The vertical migration of the seismicity ranges from a depth of approximately $19 \mathrm{~km}$ to the surface and, taking into account the mean of the variation, a variation greater than $0.6 \mathrm{~km}$ was assumed to be notable. The number of shallow events reflects the presence of the magma close to the surface and so we assumed that the number of events of magnitude greater than 3 on the same day at a depth of $0-5 \mathrm{~km}$ was significant. Finally, the strain variation has been determined with the horizontal components data of the GPS FRON station. We have assumed a significant variation when the increase or decrease was greater than $1.5 \mathrm{~mm}$ of the vector representing the horizontal deformation (composing the north and east GPS components).

\section{Results}

\subsection{Spatial probability of new vent opening}

Given its great flexibility and ability to identify the most likely zones to host new eruptions in monogenetic volcanic fields, we used the QVAST tool (Bartolini et al., 2013) to determine the susceptibility from the evolution of the seismicity during the unrest. This tool was applied first to evaluate the smoothing factors or bandwidths of the dataset analyzed, then to evaluate the probability density functions for each dataset, and, finally, to calculate the final susceptibility map (Fig. 3) (see also Fig. S1). The bandwidth is a free smoothing parameter included in the kernel function that we used to estimate the corresponding probability density functions and determines how probabilities are distributed in terms of the distance from the volcanic structures or vents (Martí and Felpeto, 2010; Bartolini et al., 2013).

In the case of the rift volcanism and the submarine layers, we applied the least square cross-validation method (LSCV) (Cappello et al., 2012; Bartolini et al., 2013) to obtain the bandwidth parameter, as it better represents the geometry of the vents distribution, NE-SW elongated (see Becerril et al., 2013). To determine the influence of seismicity in the spatial analysis, we considered that the most representative result was that obtained using Silverman's "rule of thumb" for the optimal bandwidth (Silverman, 1986). In fact, the result obtained using this method allows describing the spatial seismicity swarm distribution for the entire period, avoiding underestimation of the influence area (located close to the epicentral points) and overestimation of the density estimation (high values of the density distribution caused by small bandwidth values). Thus, we obtained a bandwidth value of
$1100 \mathrm{~m}$ for the rift volcanism and of $3900 \mathrm{~m}$ for the submarine layer, while in the case of the seismic data the range in the degree of randomness was from 500 to $1500 \mathrm{~m}$.

In the evaluation of the final susceptibility, weights were assigned based on expert opinion and on previously published work (Becerril et al., 2013, 2014) and by taking into account the average depth of the seismicity during the unrest episode. In detail, the relevance and reliability values (Table 3) (Martí and Felpeto, 2010) have been assigned as follow: relevance was given through an elicitation of expert judgment procedure (Aspinall, 2006) among the members of the Group of Volcanology of Barcelona (GVB-CSIC) and external collaborators; reliability was considered as maximum in all the datasets (value of 1).

Specifically, up to 7 October we observed no significant variation in the shallow seismicity (Table 1). In this case, we assigned the following weights: 0.5 for seismic events, 0.3 for onshore vents and fissures, and 0.2 for offshore vents and fissures. In the final period (8-10 October), we considered the shallow earthquakes as a separate layer by assigning a different and more consistent weight as follows: 0.6 for shallow seismic events, 0.2 for the remaining seismic events, 0.1 for onshore vents and fissures, and 0.1 for offshore vents and fissures.

The results shown in Fig. 3 (see also Fig. S1) highlight the importance of combining monitoring data with a previous long-term hazard assessment as a means of updating the probability of a new eruptive vent appearing in a particular area. The presence of previous volcanic structures does not provide sufficient information for forecasting the possible opening of a fresh vent during the unrest phase; however, if this information is combined with ongoing seismicity the predicted result can be improved. As shown in Fig. 3, before the eruption the area with the highest probability of a fresh vent opening is the area that is closest to the eruptive vent.

\subsection{Evolution of unrest indicators and short-term hazard assessment}

The temporal analysis of the unrest indicators was conducted by applying the ST-HASSET tool (Bartolini et al., 2016) to analyze possible patterns in the evolution of events preceding the submarine eruption on El Hierro. The advantages of this tool lie in its ability to consider different signals on the same probabilistic scale, based on any significant or abnormal change in the unrest signal, with respect to a previous stage and/or a baseline measurement considered normal. The tool computes at each stage the probability of experiencing an anomalous change (increase/decrease) by the next time bulletin, based on what has been observed up until now. With this, it helps the scientist sum up the evolution of the unrest indicators and get some insight into the possible unfolding of the volcanic crisis in the immediate future, helping with decision-making and the interpretation of the unrest. In Table 1 , we show the data for the entire unrest period and, as 

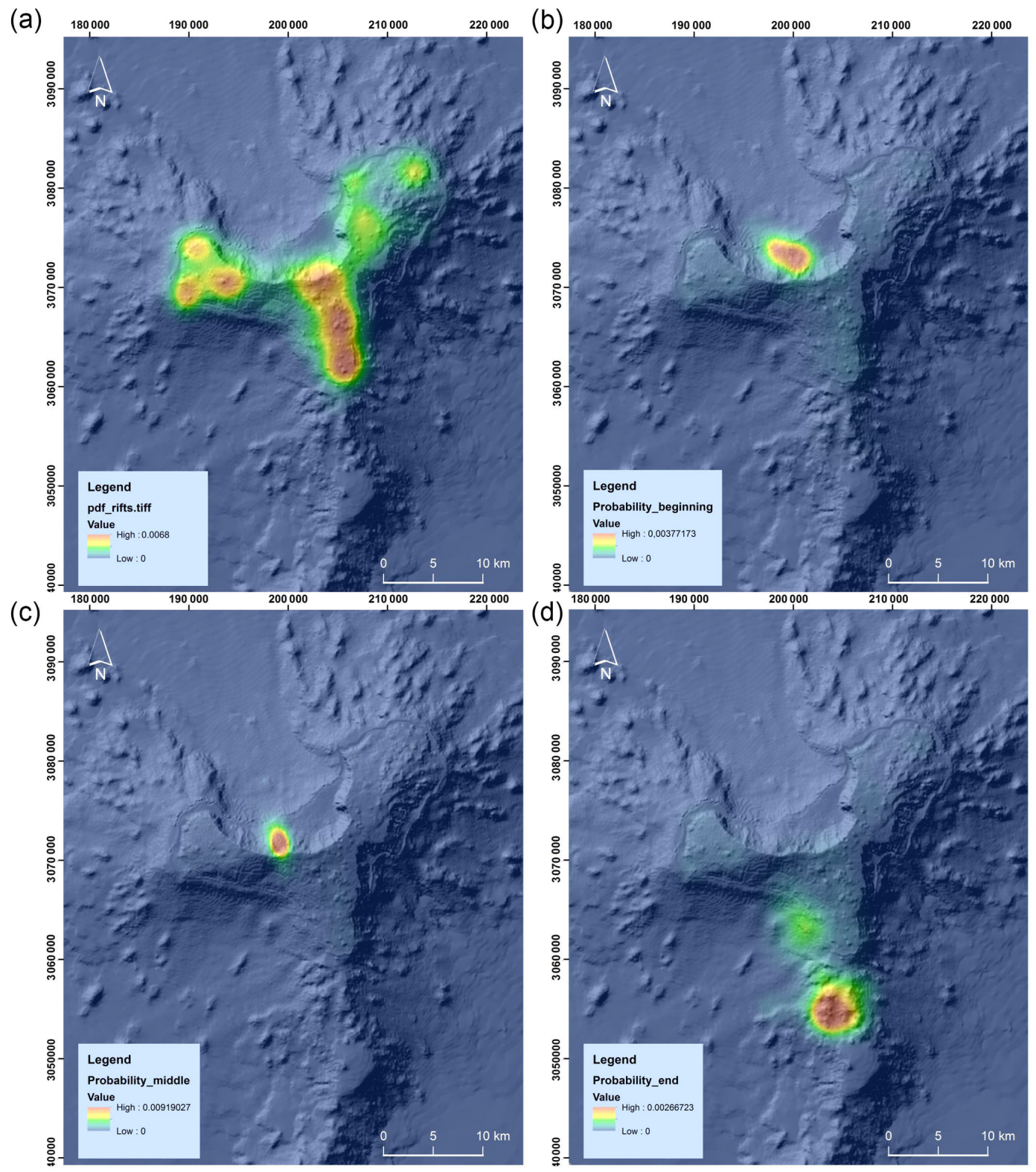

Figure 3. Susceptibility maps obtained from (a) the volcano-structural data; (b) the first days of unrest; (c) the middle of the unrest; (d) the days before the submarine eruption.

explained in Sect. 3.2.2, we considered the variation ("Y") of the indicator analyzed based on different criteria. The choice of the aleatoric and epistemic uncertainties (prior and data weights) surrounding the probability estimates were assumed considering that El Hierro unrest was the first unrest registered in Canaries. The prior weights were assumed to be the probability results of the previous bulletin (only in the first simulation we have assumed the same probability for each indicator). In the case of the data weights, we have first assigned a total epistemic uncertainty and sequentially incremented the weight with the evolution of the unrest.
In Fig. 4 and Movie S1 in the Supplement, the evolution of the indicators over the entire unrest period with a daily time window is clearly visible. On the right side of the chart, the day-by-day total number of parameters that increase or decrease during the unrest evolution is shown. We assumed a value of +1 if the indicator increases, -1 if the indicator decreases, and 0 if the change is not significant. This allows visualizing the overall tendency of variation of the unrest indicators. We also considered three phases of 28 days, all three during the evolution of the unrest period, as shown in Fig. 5, and so were able to observe how these indicators varied in different ways as the unrest evolved: 

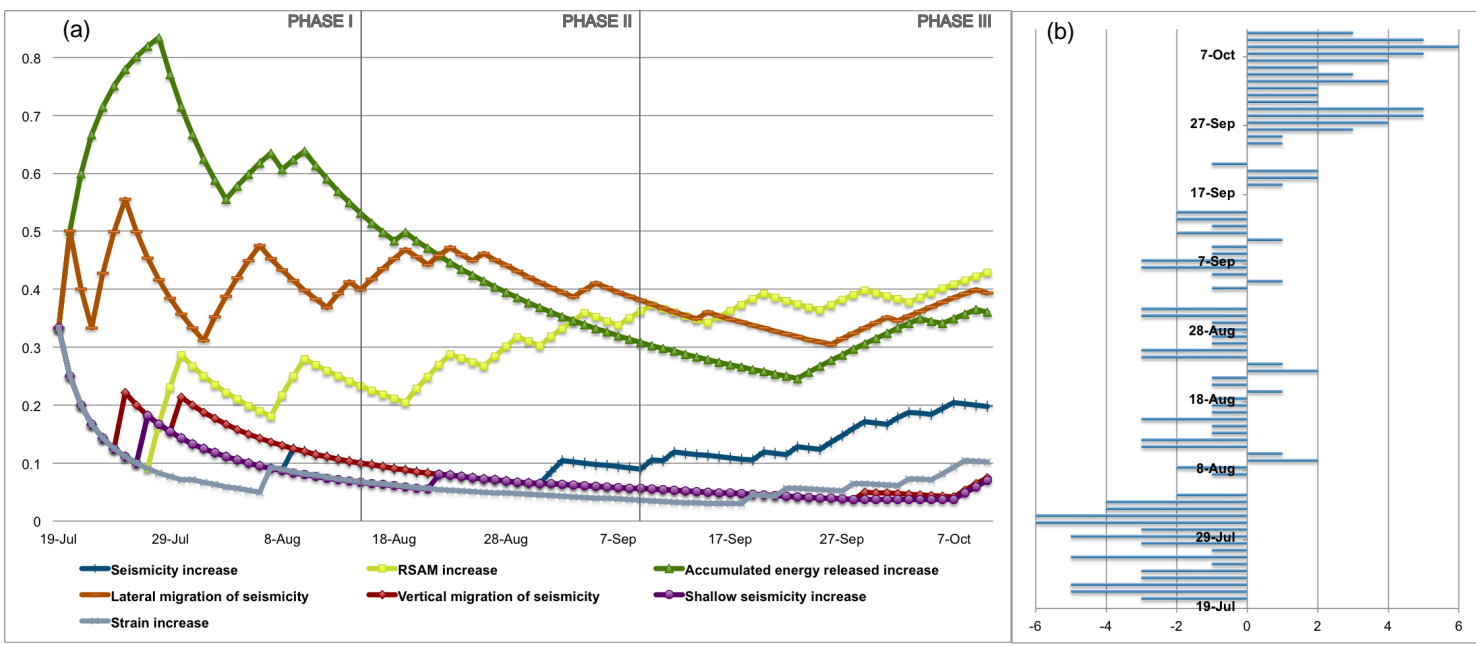

Figure 4. ST-HASSET: the evolution of the unrest indicators in three phases of 28 days. The right side of the chart shows the day-by-day tendency of variation of the unrest indicators.

- Phase I from 19 July to 15 August;

- Phase II from the 16 August to 12 September;

- Phase III from 13 September to 10 October.

By having all the precursory activity mapped and plotted into the same graph, it is easier to interpret their evolution as a whole. According to what has been defined as a significant change, in the first phase the accumulated energy released increase (AERI) and the lateral migration of seismicity (LMS) experienced a significant change, and continued overall the increasing tendency across this initial phase with periods of no significant variation followed by periods of heavy changes. By the time they enter the second phase both indicators show no changes and seem stable until well into the third phase, where AERI starts experiencing significant increases and LMS follows a few days later. As per the other indicators, in the first phase they all experience a significant change at some point in the initial stages of Phase I and seem to enter a quiet phase after that, except for the RSAM, which on average experiences a continuous increase across the three phases, perhaps more consistent though Phases II and III. The unrest indicators that seem to experience larger significant changes in Phase I are AERI, LMS, and RSAM.

Phase II was characterized by an overall stabilization of the indicators, except for RSAM, which continues to consistently increase. In addition, by the middle of this second phase the seismicity experiences a significant increase with a small period of significant lateral migration of seismicity, followed by a small jump in the RSAM a few days later. By the time the systems enters into Phase III on 12 September we continue to observe a probability increase in RSAM with a new significant jump around 18 September. This change happens simultaneously with a significant LMS increase for the first time since Phase I, and a jump in the seismicity in- crease followed by an AERI jump and strain variation. There seems to be a clear inflection point around the 20 September. This point is the first time since the beginning of the unrest 3 months ago that all unrest indicators show consistently significant changes at once. This suggests that the system has changed and is getting ready to enter into a new eruptive phase. Note that a few days before the submarine eruption there was a jump in all the indicators including for the first time the shallow seismicity and the vertical migration of seismicity; the probabilities for these two continue to increase from this moment onwards, together with RSAM, while LMS and AERI remain constant.

\section{Discussion and conclusions}

Short-term hazard assessment should always be conducted based on a previous long-term hazard assessment, as a systematic study of past eruptive activity conducted well before a new volcanic crisis starts can help forecast the most probable scenarios and thus avoid confusion regarding the potential outcome of the forthcoming eruption.

In the case of El Hierro, unfortunately, no previous hazard assessment existed, so the most probable scenario - a submarine eruption - was not anticipated, as has been shown by a subsequent study (Becerril et al., 2014). Consequently, scientific advisors and decision-makers considered possible eruptive scenarios that had much lower probabilities of occurrence, which implied making decisions with a higher cost than necessary (Sobradelo et al., 2014).

Via a retrospective analysis of the particular case of El Hierro, the results obtained in this work provide an easy and useful approach to the understanding and visualization of the information recorded by the monitoring system and show how this information can be used to forecast an erup- 

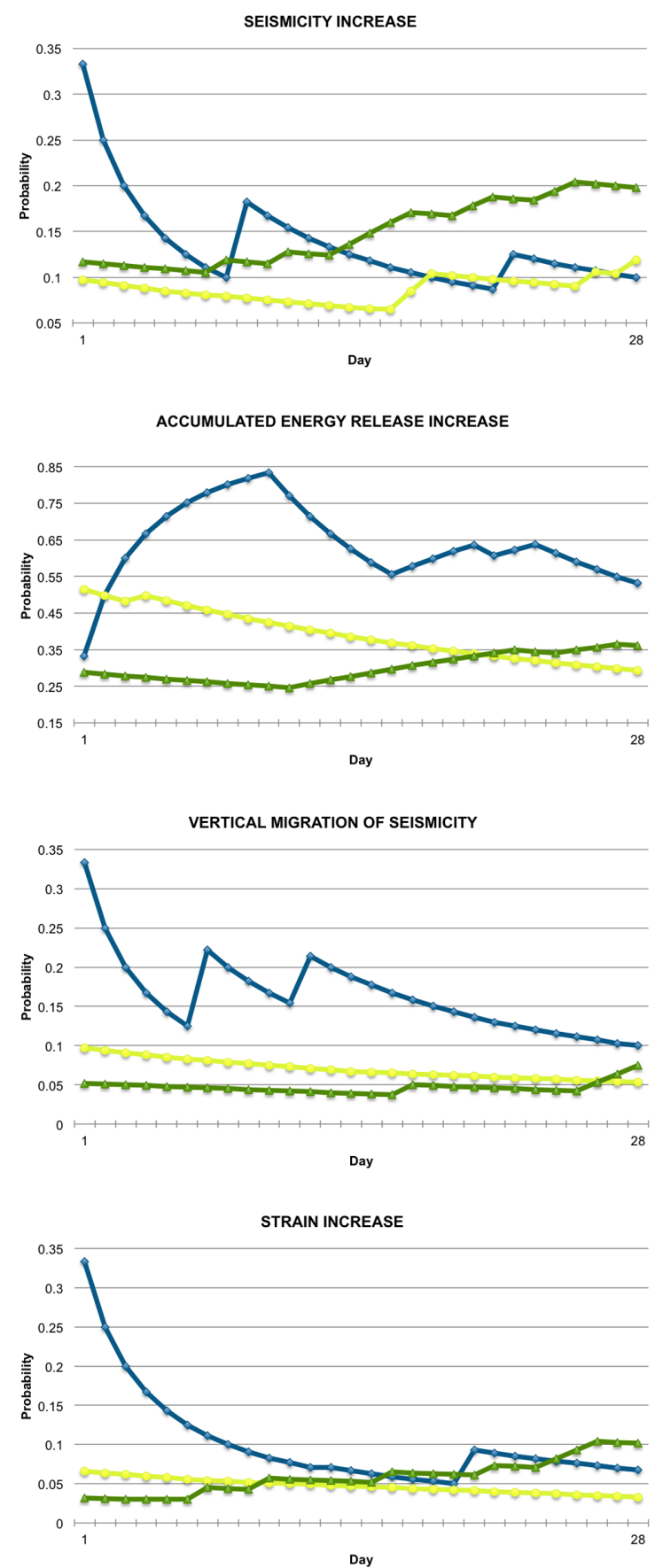
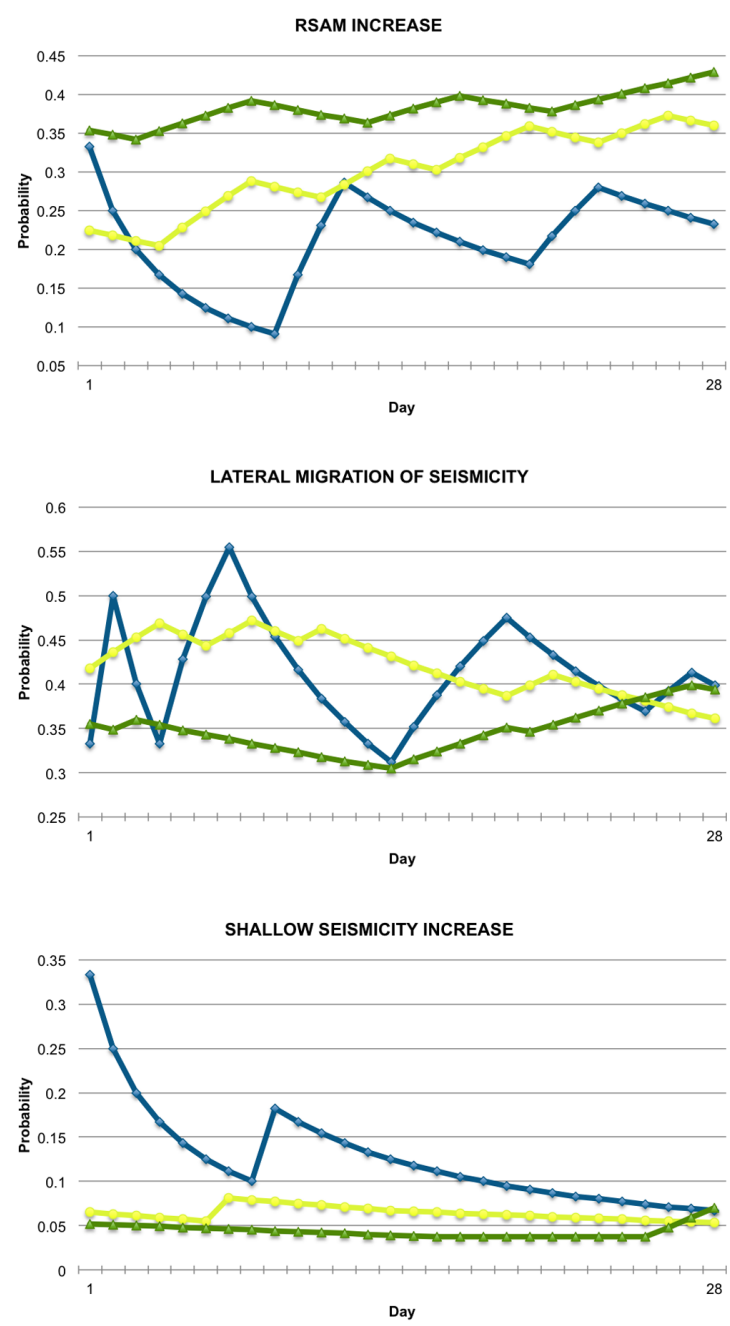

Figure 5. ST HASSET: the evolution of all indicators every 28 days (three phases of unrest).

tion and its potential hazards in real time. The translation of this information into a coherent picture that will be helpful for anticipating the future evolution of a volcanic system is not straightforward, which is why we propose that this simple methodology be used to facilitate communication among scientists and between scientists and decision-makers. Moreover, the interpretation of unrest indicators and the observation of significant variations in volcanic systems are complex tasks subject to great uncertainties and the approach pro- posed in this work aims to act as a guide for experts and decision-makers to be employed as a crisis unfolds.

Another important aspect is how to interpret monitoring signals in monogenetic volcanism. In this specific case, where the location of a future eruption is not easy to determine, the spatial probability is controlled by local and regional stress fields that are usually poorly understood. During the pre-eruptive episode on El Hierro, it was clear that the lateral migration of the magma was controlled by the 
presence of stress barriers defined by major structural and rheological discontinuities (Martí et al., 2013, 2017). This gave rise to nearly continuous changes in the probable location of the eruptive vent, which hindered the definition of a precise eruptive scenario and the application of appropriate mitigation measures. This highlights the importance of understanding monitoring signals and their interactions, as well as the need for knowledge of the past activity of the volcanic system in the form of susceptibility and hazard analyses, if a volcanic eruption is to be correctly forecast. In case of El Hierro, the susceptibility map that combines volcano-structural information and seismic data (Fig. 3) shows how the possible location of an eruptive vent varied during the evolution of the pre-eruptive unrest: initially, the magma was thought to be accumulating on the northern side of the island (Fig. 3b) but in the end it was concentrated on the southern side (Fig. 3d), where it eventually provoked a submarine eruption. This confirms the idea that seismic activity and ground deformation are good indicators of magma location in monogenetic volcanism.

The analysis of the precursors shows how special attention should be paid to each one during the evolution of the unrest period (Fig. 4). Indeed, in the initial phase, we observed obvious fluctuations in most indicators and, above all, an increase in the accumulated energy released compared to the background level. In the second phase, the behavior of these indicators remained constant and there was no significant spread, a reflection of how the magma followed the local stress field and migrated from the north to the southeast. During the final month before the eruption, we noted that the indicators started to increase sequentially but at the same hypocentral depth. However, in the final hours before the eruption the presence of very shallow seismicity indicated that, immediately after the final major earthquake, a relatively rapid vertical migration of magma was taking place. This vertical ascent to the surface was associated with a drastic decrease in both the number of seismic events (almost no seismicity of any kind in the $30 \mathrm{~h}$ before the onset of the eruption) in the accumulated energy release, and in the deformation, but also with an increase in the RSAM, thereby suggesting that the final major tectonic earthquake facilitated a path for the magma to reach the surface (Martí et al., 2013).

From an emergency management perspective, it is worth stressing two further important results of the application of our method. Firstly, it identified unmistakably the anomalous behavior of the activity, characterized by an increasing probability in almost all indicators during the first days of the unrest period as they varied in relation to the background values. Secondly, many indications suggested that the probability of an eruption increased in almost all parameters from 25 September until the onset of the eruption. On 23-27 September, the Canarian civil protection authorities in charge of the management of the volcanic crisis changed the alert level for the population from green to yellow in two areas due to the strong seismicity being felt by the population and the risk of rock falls near populated areas. On 10 October, the appearance of an increasingly strong seismic tremor signal in the monitoring network warned of the imminent onset of the eruption and civil protection raised the alert level to red. Despite the correct management of the eruption crisis on El Hierro by the Canarian civil protection, we still believe that our results can improve significantly the island's early warning capability during an unrest period characterized by a high level of uncertainty. Thus, the tools presented here could have been very useful for the Canarian civil protection during the October 2011 eruption crisis.

Data availability. Data used in this paper are published on the IGN web page: http://www.ign.es/web/ign/portal/vlc-serie-hierro (last access: 4 June 2018).

Supplement. The supplement related to this article is available online at: https://doi.org/10.5194/nhess-18-1759-2018-supplement.

Competing interests. The authors declare that they have no conflict of interest.

Acknowledgements. This research was funded by the European Commission (EC ECHO Grant SI2.695524: VeTOOLS). The authors would like to thank the Instituto Geográfico Nacional (IGN - Madrid), and especially Rafael Abella Meléndez, for helping to access the monitoring data. Joan Martí is grateful for the MECD (PRX16/00056) grant. The authors are grateful to anonymous reviewers for their insightful comments and thorough review of the manuscript, which has helped us improve considerably this work. The English text was edited by Michael Lockwood.

Edited by: Giovanni Macedonio

Reviewed by: two anonymous referees

\section{References}

Aspinall, W. P.: Structured elicitation of expert judgment for probabilistic hazard and risk assessment in volcanic eruptions, in: Statistics in volcanology, edited by: Mader, H. M., Coles, S. G., Connor, C. B., and Connor, L. J., Special Publication of IAVCEI,Geological Society of London, 2006.

Bartolini, S., Cappello, A., Martí, J., and Del Negro, C.: QVAST: a new Quantum GIS plugin for estimating volcanic susceptibility, Nat. Hazards Earth Syst. Sci., 13, 3031-3042, https://doi.org/10.5194/nhess-13-3031-2013, 2013.

Bartolini, S., Sobradelo, R., and Martí, J.: ST-HASSET for volcanic hazard assessment: A Python tool for evaluating the evolution of unrest indicators, Comput. Geosci., 93, 77-87, https://doi.org/10.1016/j.cageo.2016.05.002, 2016.

Becerril, L., Cappello, A., Galindo, I., Neri, M., and Del Negro, C.: Spatial probability distribution of future volcanic eruptions at El 
Hierro Island (Canary Islands, Spain), J. Volcanol. Geoth. Res., 257, 21-30, https://doi.org/10.1016/j.jvolgeores.2013.03.005, 2013.

Becerril, L., Bartolini, S., Sobradelo, R., Martí, J., Morales, J. M., and Galindo, I.: Long-term volcanic hazard assessment on El Hierro (Canary Islands), Nat. Hazards Earth Syst. Sci., 14, 18531870, https://doi.org/10.5194/nhess-14-1853-2014, 2014.

Blong, R.: Volcanic hazards and risk management, in: Encyclopedia of volcanoes, edited by: Sigurdsson, H., Houghton, B., McNutt, S., Rymer, H., and Stix, J., Academic Press, San Diego, 12151227, 2000.

Cappello, A., Neri, M., Acocella, V., Gallo, G., Vicari, A., and Del Negro, C.: Spatial vent opening probability map of Etna volcano (Sicily, Italy), B. Volcanol., 74, 2083-2094, https://doi.org/10.1007/s00445-012-0647-4, 2012.

Carniel, R., Tárraga, M., Jaquet, O., and García, A.: On the memory of seismic noise recorded at Teide-Pico Viejo volcanic complex, Tenerife, Spain, EGU06-A-01929, NH5.03-1WE2P-0679, EGU General Assembly, Vienna, 2006.

Chouet, B.: Long period volcano seismicity: Its source and use in eruption forecasting, Nature, 380, 309-316. https://doi.org/10.1038/380309a0, 1996.

Connor, C. B. and Conway, F. M.: Basaltic Volcanic Fields, in Encyclopedia of Volcanology, Academic Press, 331-343, 2000.

Connor, C. B., Sparks, R. S. J., Mason, R. M., Bonadonna, C., and Young, S. R.: Exploring links between physical and probabilistic models of volcanic eruptions: The Soufrière Hills Volcano, Montserrat, Geophys. Res. Lett., 30, 1701, https://doi.org/10.1029/2003GL017384, 2003.

Domínguez Cerdeña, I., del Fresno, C., and Gomis Moreno, A.: Seismicity patterns prior to the 2011 El Hierro eruption, B. Seismol. Soc. Am., 104, 567-575, https://doi.org/10.1785/0120130200, 2014.

Endo, T. E. and Murray, T.: Real-time Seismic Amplitude Measurement (RSAM). A volcano monitoring and prediction tool, B. Volcanol., 53, 533-545, 1991.

Geyer, A., Martí, J., and Villaseñor, A.: First-order estimate of the Canary Islands plate-scale stress field: Implications for volcanic hazard assessment, Tectonophysics, 679, 125-139, https://doi.org/10.1016/j.tecto.2016.04.010, 2016.

Guillou, H., Carracedo, J. C., Pérez-Torrado, F. J., and Rodríguez Badiola, E.: K-Ar ages and magnetic stratigraphy of a hotspotinduced, fast grown oceanic island: El Hierro, Canary Islands, J. Volcanol. Geoth. Res., 73, 141-155, 1996.

Harrington, R. M. and Brodsky, E. E.: Volcanic hybrid earthquakes that are brittle-failure events, Geophys. Res. Lett., 34, L06308, https://doi.org/10.1029/2006GL028714, 2007.

Jaquet, O. and Carniel, R.: Multivariate stochastic modelling: towards forecasts of paroxysmal phases at Stromboli, J. Volcanol. Geoth. Res., 128, 261-271, 2003.

Jaquet, O., Sparks, R. S. J., and Carniel, R.: Magma memory recorded by statistics of volcanic explosions at the Soufrière Hills Volcano, Montserrat in Statistics in Volcanology, Special Publications of IAVCEI, edited by: Mader, H. M., Coles, S., and Connor, C., vol. 1, 175-184, 2006.

Jaquet, O., Connor, C. B., and Connor, L.: Probabilistic Methodology for Long Term Assessment of Volcanic Hazards, IHLRMW, Las Vegas, USA, 2008.
Jellinek, A. M. and Bercovici, D.: Seismic tremors and magma wagging during explosive volcanism, Nature, 470, 522-526, 2011.

Lavallée, Y., Meredith, P. G., Dingwell, D. B., Hess, K. U., Wassermann, J., Cordonnier, B., Gerik, A., and Kruhl, J. H.: Seismogenic lavas and explosive eruption forecasting, Nature, 453, 507 510, 2008.

López, C., Blanco, M. J., Abella, R., Brenes, B., CabreraRodríguez, V. M., Casas, B., Domínguez-Cerdeña, I., Felpeto, A., Fernández de Villalta, M., del Fresno, C., García, O., GarcíaArias, M. J., García-Cañada, L., Gomis-Moreno, A., GonzálezAlonso, E., Guzmán-Pérez, J., Iribarren, I., López-Díaz, R., Luengo-Oroz, N., Meletlidis, S., Moreno, M., Moure, D., Pereda de Pablo, J., Rodero, C., Romero, E., Sainz-Maza, S., SentreDomingo, M. A., Torres, P. A., Trigo, P., and Villasante-Marcos, M.: Monitoring the unrest of El Hierro (Canary Islands) before the onset of the 2011 Submarine Eruption, Geophys. Res. Lett., 39, L13303, https://doi.org/10.1029/2012GL051846, 2012.

López, C., Martí, J., Abella, R., and Tárraga, M.: Applying fractal dimensions and energy-budget analysis to characterize fracturing processes during magma migration and eruption: 2011-2012 El Hierro (Canary Islands) submarine eruption, Surv. Geophys., 35, 1023-1044, https://doi.org/10.1007/s10712-014-9290-2, 2014.

López, C., Benito-Saz, M. A., Martí, J., del-Fresno, C., García-Cañada, L., Albert, H., and Lamolda, H.: Driving Magma to the Surface: the 2011-2012 El Hierro Volcanic Eruption, Geochem. Geophy. Geosy., 18, 3165-3184, https://doi.org/10.1002/2017GC007023, 2017.

Martí, J. and Felpeto, A.: Methodology for the computation of volcanic susceptibility. An example for mafic and felsic eruptions on Tenerife (Canary Islands), J. Volcanol. Geoth. Res., 195, 69-77, https://doi.org/10.1016/j.jvolgeores.2010.06.008, 2010.

Martí, J., Pinel, V., López, C., Geyer, A., Abella, R., Tárraga, M., Blanco, M. J., Castro, A., and Rodríguez, C.: Causes and mechanisms of the 2011-2012 El Hierro (Canary Islands) submarine eruption, J. Geophys. Res.-Sol. Ea., 118, 823-839, https://doi.org/10.1002/jgrb.50087, 2013.

Martí, J., López, C., Bartolini, S., Becerril, L., and Geyer, A.: Stress controls of monogenetic volcanism: a review, Front. Earth Sci., 4, 106, https://doi.org/10.3389/feart.2016.00106, 2016.

Martí, J., Villaseñor, A., Geyer, A., López, C., and Tryggvason, A.: Stress barriers controlling lateral migration of magma revealed by seismic tomography, Scientific Reports, 7, 40757, https://doi.org/10.1038/srep40757, 2017.

Martin, A. J., Umeda, K., Connor, C. B., Weller, J. N., Zhao, D., and Takahashi, M.: Modeling long-term volcanic hazards through Bayesian inference: an example from the Tohuku volcanic arc Japan, J. Geophys. Res., 109, B10208, https://doi.org/10.1029/2004JB003201, 2004.

Marzocchi, W., Sandri, L., and Selva, J.: BET_EF: A probabilistic tool for long- and short-term eruption forecasting, B. Volcanol., 70, 623-632, 2008.

McNutt, S.: Seismic monitoring and eruption forecasting of volcanoes: A review of the state of the art and case histories, in: Monitoring and mitigation of volcano hazards, edited by: Scarpa, R. and Tilling, R. I., Springer, Berlin, 99-146, 1996.

McNutt, S. R.: Volcano Seismology, Ann. Rev. Earth Planet. Sc., 33, 461-491, 2005. 
Neuberg, J., Luckett, R., Baptie, B., and Olsen, K.: Models of tremor and low-frequency earthquake swarms on Montserrat, J. Volcanol. Geoth. Res., 101, 83-104, 2000.

Papale, P.: Strain-induced magma fragmentation in explosive eruptions, Nature, 397, 425-428, 1999.

Phillipson, G., Sobradelo, R., and Gottsmann, J.: Global volcanic unrest in the 21st century: An analysis of the first decade, J. Volcanol. Geoth. Res., 264, 183-196, 2013.

Scarpa, R. and Tilling, R. I.: Monitoring and Mitigation of Volcano Hazards, Springer-Verlag, Berlin, 1996.

Silverman, B. W.: Density Estimation for Statistics and Data Analysis, Chapman \& Hall, London, 1986.

Sparks, R. S. J.: Forecasting volcanic eruptions, Earth Planet. Sc. Lett., 210, 1-15, 2003.

Sobradelo, R. and Martí, J.: Short-term volcanic hazard assessment through Bayesian inference: Retrospective application to the Pinatubo 1991 volcanic crisis, J. Volcanol. Geoth. Res., 290, $1-11,2015$.

Sobradelo, R., Martí, J., Kilburn, C., and López, C.: Probabilistic approach to decision-making under uncertainty during volcanic crises: retrospective application to the El Hierro (Spain) 2011 volcanic crisis, Nat. Hazards, 76, 979-998, https://doi.org/10.1007/s11069-014-1530-8, 2014.

Stein, R.: The role of stress transfer in earthquake occurrence, Nature, 402, 605-609, 1999.

Tárraga, M., Carniel, R., Ortiz, R., Marrero, J. M., and García, A.: On the predictability of volcano-tectonic events by low frequency seismic noise analysis at Teide-Pico Viejo volcanic complex, Canary Islands, Nat. Hazards Earth Syst. Sci., 6, 365-376, https://doi.org/10.5194/nhess-6-365-2006, 2006.
Tárraga, M., Martí, J., Abella, R., Carniel, R., and López, C.: Volcanic tremors: good indicators of change in plumbing systems during volcanic eruptions, J. Volcanol. Geoth. Res., 273, 33-40, https://doi.org/10.1016/j.jvolgeores.2014.01.003, 2014.

Telesca, L., Lovallo, M., Martí, J., López, C., and Abella, R.: Using the Fisher-Shannon method to characterize continuous seismic signal during volcanic eruptions: application to 2011-2012 El Hierro (Canary Islands) eruption. Revealing dynamic changes on El Hierro (Canary Islands) during the 2011-2012 eruption through investigation of the continuous seismic signal, Terra Nova, 26, 425-429, 2014.

Telesca, L., Lovallo, M., Martì, J., López, C., and Abella, R.: Multifractal investigation of continuous seismic signal recorded at El Hierro volcano (Canary Islands) during the 2011-2012 pre- and eruptive phases, Tectonophysics, 642, 71-77, 2015.

Tonini, R., Sandri, L., Rouwet, D., Caudron, C., Marzocchi, W., and Suparjan: A new Bayesian Event Tree tool to track and quantify volcanic unrest and its application to Kawah Ijen volcano, Geochem. Geophy. Geosy., 17, 2539-2555, https://doi.org/10.1002/2016GC006327, 2016.

Vallianatos, F., Michas, G., Papadakis, G., and Tzanis, A.: Evidence of non-extensivity in the seismicity observed during the 20112012 unrest at the Santorini volcanic complex, Greece, Nat. Hazards Earth Syst. Sci., 13, 177-185, https://doi.org/10.5194/nhess13-177-2013, 2013. 